\title{
Student's Perceptions of the Community Impact of Social Education Degree Internship
}

\author{
Esperança Jales Ribeiro $^{\mathrm{a} *}$, Emília Martins $^{\mathrm{b}}$, Maria João Amante ${ }^{\mathrm{c}}$, Sara \\ Alexandre Felizardo $^{d}$, Rosina Fernandes ${ }^{e}$, Lia Araújo $^{f}$ \\ * Corresponding author: Esperança Jales Ribeiro, esperancaribeiro@esev.ipv.pt \\ a Instituto Politécnico de Viseu e CI\&DETS, Viseu, Portugal, esperancaribeiro@esev.ipv.pt \\ ${ }^{b}$ Instituto Politécnico de Viseu e CI\&DETS,Viseu,Portugal,emiliamartins@esev.ipv.pt \\ ${ }^{c}$ Instituto Politécnico de Viseu e CI\&DETS, Viseu, Portugal, majoa@esev.ipv.pt \\ ${ }^{d}$ Instituto Politécnico de Viseu e CI\&DETS,Viseu, Portugal, sfelizardo@esev.ipv.pt \\ ${ }^{e}$ Instituto Politécnico de Viseu e CI\&DETS, Viseu Portugal, rosina@esev.ipv.pt \\ ${ }^{f}$ Instituto Politécnico de Viseu e CI\&DETS, Viseu, Portugal, liajaraujo@esev.ipv.pt
}

\begin{abstract}
http://dx.doi.org/10.15405/epsbs.2016.11.22

Evaluating the impact of an intervention is a very important stage in social educators' practice, since it allows them to improve the quality of socio-educational projects. The aim of this study is to rethink the internship of the social education degree through students' perceptions about the impact of their projects in the community. This is a qualitative and exploratory study using documental analysis of 50 internship final reports of a social education degree from a Portuguese polytechnic higher education institution and whose emerging categorical content analysis was performed with NVivo software. The analysis revealed four distinct indicators linked to the project (accomplished objectives, evaluation of activities, sustainability and innovation), the target group (participation, motivation and benefits), the institution (satisfaction of collaborators, improved dynamic, routines and space enhancements), and the students (relational, reflexive and planning skills; satisfaction). It also revealed instruments, feedback, observation, document analysis and case reports as means of verification. The use of indicators related to the project's objectives, the changes perceived from the benefits in the target-group and in the institution, and the interveners' level of satisfaction should be noted as positive. Given the inconsistency in the use of formal assessment instruments, the results show the need to strengthen students' mobilisation of project assessment skills in order to improve the quality of undergraduate education.
\end{abstract}

CC 2016 Published by Future Academy www.FutureAcademy.org.uk

Keywords: Social education; Practicum impact; Quality. 


\section{Introduction}

\subsection{Social Education and Community Development}

Social education is the educational response to emerging and ongoing societal challenges through the restoration and expansion of educational opportunities for persons and social groups, to their full realization as social beings (Caride, 2005). The social educator emerges as the professional intervening with individuals and their respective contexts, in order to promote personal and social development, integration and community participation (Alonso-Díaz, 2014).

The practice of social educator is mainly communitarian in that it supposes acting in a specific context, on concrete problems where individuals, groups, associations and institutions are assumed as main actors (Barrio, 2007). As shown by Caride, Pereira and Vargas (2007), the community is assumed as a social living space where relationships and social interactions are established as a function of territorial and cultural meanings, as well as individual and collective experiences. Social educators, recognizing the importance of these structural factors, seek to involve individuals in transforming their own realities, using mediation and education as means to promote individuals' ability to involve personal resources, be autonomous, decide and control. That is, through actions of proximity, cooperation and exchange, Social educators initiate, develop and consolidate socio-educational processes to empower individuals and groups (Crespo, 2010).

\subsection{Internship in Training Social Educators}

Higher education in social education includes internships, which provide an opportunity to place students in specific work contexts, bringing them closer to the social and political dynamics with which they will have to deal in their future careers (Domínguez \& Blanch, 2013). The approximation between the professional and training settings is assumed as an important stage in the higher formation process of social educators, in the sense that it is an opportunity for reflection and improvement of the scientific and technical knowledge, based on concrete work (Duta, Forés, \& Novella, 2015). This is curricular synthesis opportunity, resulting in acquiring and mobilising knowledge in a practical context. Thus, all pratical initiatives, such as the internship, will allow the conceptual and contextual foundations for the profession to be consolidated, as well as provide learning and training of techniques, which are means and resources for the socio-educational intervention.

These skills are promoted through the development of socio-educational intervention projects, defined according to the specificities of the context and the social educator's skills profile. The elaboration of the projects developed in the internship is based on two premises, taken as essential by the reference literature: i) social education responds to a complex set of social needs of individuals, through restoring and expanding educational opportunities for people and social groups, aiming to promote cultural, social and economic inclusion (Caride, 2005); ii) socio-educational processes are directed primarily to developing the sociability of the subjects, especially targeting individuals or groups in social conflict, and occur in non-formal educational contexts or environments (Romans, Petrus \& Trilla, 2003). 
Thus, at the School of Education, of the Polytechnic Institute of Viseu, the internship, which appears in the third and final year of the study plan, is developed in community and/or institutional contexts, with different age groups (children, adolescents, youths, adults, elderly) and various social problems and needs (situations of institutionalisation in terms of child protection measures, special educational needs, unemployment, loneliness and social isolation, poverty, etc.). In this sense, this higher education institution has celebrated internship protocols with various host institutions such as local municipalities, private social welfare institutions, schools, prisons and health centres, among others.

\subsection{Assessing the Impact on the Community of the Social Educator's Internship}

In the context of social work, it is urgent that professionals develop coordinated intervention strategies in the planning, implementation and assessment of the community actions (Crespo, 2010). Assessment should be constant, encompassing the whole process, in the sense that: i) at an earlier stage (diagnosis), it allows to identifies the needs, interests and capabilities of institutions, professionals and clients (Serrano, 2008); ii) during the implementation of the project, it allows to monitor and identify the positive and negative aspects of the intervention and the strategies used with implications for decisions taken to improve the quality of the social projects (Barrio, 2007); iii) finally, it makes possible to check the immediate effects (short-term) of the intervention and measure whether the specific objectives have been achieved; iv) in the medium and long term, it measures whether the purpose of the project was achieved.

Assessing the impact of the intervention, by analysing the levels of achievement of the objectives and the use of the resources involved, allows us to understand the extent to which the actions taken have been successful or unsuccessful (Capucha, 2008). This assessment focuses on the short term lasting changes identified in the context, according to the defined objectives. To do this, the initial situation, as the diagnosis characterised it, is compared with the end point situation, giving a sense of what has changed as a result of the intervention (Capucha, 2008). The efficacy of the intervention focuses on the degree and timing of the implementation of the general and specific objectives as well as the purpose of the project (Pena, 2005). It assesses the effects on individuals achieved by the intervention applied in ideal/optimal conditions (potential benefit). This is distinct from effectiveness because this refers to the real benefit obtained in standard conditions while efficiency is the relationship between the results obtained by the intervention and the resources used (cost-benefit) (Newcomer, Hatry \& Wholey, 2015; Silva \& Barros, 2015). In short, it is important for the assessment to be useful, reliable, ethical and accurate, as well as objective, valid, timely and practical (Serrano, 2008).

\section{Problem statement}

Assessing the impact of the internship on the community where the socio-educational intervention projects are developed, is a fundamental step for reflecting and reappraising the training of social educators. It is intended to be carried out by students, but also by trainers, especially those who have 
eISSN: 2357-1330

Selection \& Peer-review under responsibility of the Conference Organization Committee

responsibilities in designing and monitoring the internship model and projects. As part of the degree in social education at the School of Education, of the Polytechnic Institute of Viseu, after implementing the project, a final internship report is required with a critical reflection on the impact of each project in the community. It is important to understand the perception of the interns about the impact of their training on the community, taken from the reports content, in order to identify the indicators and means of verification upon which they are based.

\section{Research questions}

Based on the problem stated above, we defined the specific study question: which indicators and which means of monitoring the impact on the community emerge from analysing the content of the final internship reports?

\section{Purpose of the study}

From the content analysis of the final internship reports, we intend to collect information about the indicators and means of verification reported in the internship's impact assessment. This information will allow us to reflect upon and rethink the practices and project assessment methodologies with the aim of improving the quality of learning.

\section{Research methods}

This is a qualitative and exploratory study, using the documental analysis of final internship reports. The reports targeted for analysis relate to supervised socio-educational interventions, developed in the internship of the degree in social education at the School of Education, of the Polytechnic Institute of Viseu, during the academic year 2015/2016 with a total of 520 contact hours. The analysis focused exclusively on the contents of the assessment of the impact of the intervention on the community as defined in the project.

Excerpts from 50 final internship reports were analysed. These present socio-educational intervention projects were developed in institutional and community settings, which include 23 in local municipalities, 20 in social solidarity institutions, 9 in schools and 3 entities linked to the Ministry of Justice, covering various target groups, from the general community, children, youths, adults and the elderly, to more specific audiences such as multi-challenged families, people with special needs, prisoners and other people in fragile situations.

From the analysis of five randomly selected reports, a preliminary draft of the categorical system was prepared, enabling an orientation for the reading and analysis which followed. The theme was defined as the recording unit and the subchapter as the context unit, having followed the enumeration rule of coding each topic only once in each report. The rules of comprehensiveness, relevance, objectivity/reliability and exclusivity were followed (Bardin, 2015). Before the final categorization, we 
proceeded to determine fidelity between encoders, using three researchers, who were knowledgeable of the objectives and methodology of the study. They codified the same information independently, regardless of the previous discussions on the predefined categories (Yardley, 2008). The levels of agreement were $98 \%$.

The emerging categorical content analysis involved the use NVivo software, version 11.

\section{Findings}

The reading from the perspective of students about the impact of the internship on the community present in their final reports allowed to identify the indicators considered in the presentation of the impact of the internship (Table 1) and the means of verification to support these indicators (Table 2). The value appreciation regarding the impact of the internship was not taken into account, because it was always mentioned as positive.

As for the first dimension, assessment indicators, four categories were identified: target-group (representing $41.5 \%$ of total mentions), intern (21.5\%), project (18.4\%) and host institution (15.0\%). Within the target-group category, three subcategories were created: benefits $(38.4 \%)$, motivation (32.6\%) and participation (29.0\%)

The most representative subcategory relates to the target-group's benefits, with arguments related to social gains (e.g., greater interaction between individuals), cognitive gains (e.g., better performance), gains in self-esteem, autonomy and behaviour. Examples of such arguments are: "The acquisition of some key elements [by the clients] related to daily activities was notorious" (report 24), for autonomy; "[The clients] realized that they had dreams to fulfil, that they should fight for them when they returned to freedom [incarcerated prisoners] and that despite the difficulties they may have, with dedication they will be able to do it and not return to crime" (report 33) about the purpose of life. As for motivation, it was also mentioned that "The clients showed great interest and commitment for the tasks, showing some anxiety for the following week" (report 24).

Table 1. Assessment of Impact of Internship on the Community- Dimension: Indicators

\begin{tabular}{|c|c|c|c|c|}
\hline Categories & Subcategories & Freq. & $\begin{array}{l}\% \text { of the } \\
\text { subcategories }\end{array}$ & $\begin{array}{l}\text { \% of the } \\
\text { categories }\end{array}$ \\
\hline \multirow[t]{4}{*}{ Target group } & Benefits & 33 & 38.4 & \\
\hline & Motivation & 28 & 32.6 & \\
\hline & Participation & 25 & 29.0 & \\
\hline & Total of the category & 86 & 100 & 41.5 \\
\hline \multirow[t]{5}{*}{ Intern } & Relational skills & 22 & 42.3 & \\
\hline & Planning skills & 20 & 38.5 & \\
\hline & Personal satisfaction & 6 & 11.5 & \\
\hline & Skills of reflection & 4 & 7.7 & \\
\hline & Total of the category & 52 & 100 & 25.1 \\
\hline \multirow[t]{5}{*}{ Project } & Achieving objectives & 19 & 50 & \\
\hline & Sustainability & 10 & 26.3 & \\
\hline & Assessment of activities & 7 & 18.4 & \\
\hline & Innovation & 2 & 5.3 & \\
\hline & Total of the category & 38 & 100 & 18.4 \\
\hline
\end{tabular}




\begin{tabular}{llccc}
\hline Host Institution & Extending dynamics & 15 & 48.4 & \\
& Satisfaction of collaborators & 9 & 29.0 & \\
& Creating routines & 4 & 12.9 & \\
& Improvements to physical space & 3 & 9.7 & 15.0 \\
\cline { 2 - 5 } & Total of the category & 31 & 100 & 100 \\
\cline { 2 - 4 } & Total of the dimension & 207 & & \\
\hline
\end{tabular}

In the intern category, the subcategories identified were relational $(42.3 \%)$, planning $(38.5 \%)$ and reflection skills (7.7\%), and personal satisfaction (11.5\%), illustrated by the following statements: "We may consider that our presence in the parish council was appreciated since the relationship that has been established between us and the clients is remarkable" (report 13), for the relational skills; "We always try to enhance appealing activities and that would precisely meet the interests [of the participants]" (report 24), for the skills of planning.

Within the project category, four subcategories were identified with decreasing values: achieving objectives (50\%), sustainability (26.3\%), assessment of activities (18.4\%) and innovation (5.3\%). About this last category, it was noted that "We left our mark because we brought some innovation and creativity." (report 1). With regard to the first subcategory, "As for the objectives defined in the internship project, I think that generally speaking, they have been achieved" (report 5).

Finally, the category on the host institution included as subcategories: extending dynamics (48.4\%), satisfaction of collaborators (29\%), creating routines $(12.9 \%)$ and improvement of the physical space (9.7\%). As an example of the most representative subcategory within the host institution, statements such as the following are identified: "The fact that we bet on performing intergenerational activities meant that people participated on a larger scale, because the fact that there could be parents, children and even grandparents together in the same activity facilitates what would otherwise be a problem, that is, where to leave the children" (report 30).

In the second dimension, means of monitoring the impact of the internship on the community, two categories were identified (Table 2): unstructured records, representing $57.5 \%$ of mentions, and structured records $(42.5 \%)$. Within the first category, informal talks $(57.8 \%)$ and implicit observation (41.3\%) were considered. The second included constructed instruments $(41.1 \%)$, document analysis (20.6\%), case report $(11.8 \%)$, attendance records $(11.8 \%)$, direct observation $(8.8 \%)$ and existing instruments $(5.9 \%)$.

Table 2. Assessment of Impact of Internship on the Community- Dimension: Means of monitoring

\begin{tabular}{|c|c|c|c|c|}
\hline Categories & Subcategories & Freq. & $\begin{array}{l}\text { \% of the } \\
\text { subcategories }\end{array}$ & $\begin{array}{l}\text { \% of the } \\
\text { categories }\end{array}$ \\
\hline \multirow{4}{*}{$\begin{array}{l}\text { Unstructured } \\
\text { records }\end{array}$} & Feedback - informal conversations & 27 & 58.7 & \\
\hline & Implicit observation & 19 & 41.3 & \\
\hline & Total of the category & 46 & 100 & 57.5 \\
\hline & Constructed instruments & 14 & 41.1 & \\
\hline \multirow{7}{*}{$\begin{array}{l}\text { Structured } \\
\text { records }\end{array}$} & Document analysis & 7 & 20.6 & \\
\hline & Case report & 4 & 11.8 & \\
\hline & Attendance records & 4 & 11.8 & \\
\hline & Direct observation & 3 & 8.8 & \\
\hline & Existing instruments & 2 & 5.9 & \\
\hline & Total of the category & 34 & 100 & 42.5 \\
\hline & Total of the dimension & 80 & & 100 \\
\hline
\end{tabular}




\section{Conclusions}

Regarding the assessment indicators, there is a variety and scope because aspects related to themselves (i.e., the category, interns), to the context (i.e., host institution), to the project itself and to the target group have been identified. The highest value was found in the target group, centred on the number of participants and their interest, specially on the benefits observed in the people who underwent the intervention. This focus on the benefits is mentioned in the methodologies addressed in preparing the projects for previous internship courses (Pena, 2005; Serrano, 2008). Similarly, in other studies within the same area of training, it was concluded that the analysis of the impact tended towards that indicator, showing the changes perceived in the project participants (Araújo et al., 2014).

In the project assessment from the reference to the contribution of the interns themselves, is worth highlighting the predominance of mentions of their relational skills, which transmit the value of interpersonal skills in the intervention of social educators, as recognized by the International Association of Social Educators (AIEJI, 2006).

Reflecting on the impact of the internship, students tend to consider aspects predominantly related to indicators rather than the means of monitoring used. Nevertheless, the use of some constructed instruments should be noted, which was the more commonly reported subcategory in the structured means of assessment. This indicates that the use of this type of strategy should be increased. In turn, monitoring based on unstructured records resorting to memories reinforces the need for greater investment in this area.

The inconsistency of using formal assessment instruments leading to gaps in collecting and obtaining reliable data to sustain and support the assessment results should be object of further development, analysis and reflection. In our opinion, it may translate difficulties in terms of selecting/creating instruments and recognising the importance of using them. But it also highlights the need to detect any gaps in training in these content areas that must be understood in order to overcome them. Finally, this reflects a structural aspect concerning the definition of an assessment methodology based on the objectives of the intervention as a key pillar of efficacy, effectiveness and efficiency. The development of practices based on evidence is considered a core function of social work. Promoting skills that foster this should be ensured in the curriculum (Moore \& Avant, 2008) for improving the quality of higher education for social educators. We emphasize the importance of these internal assessments which allow us to monitor the paths to training courses and gauge the adequacy of the recommended models and the results actually achieved.

\section{Acknowledgements}

To the Centre for Studies in Education, Technologies and Health (CI\&DETS) at the Polytechnic Institute of Viseu, Portugal. 


\section{References}

Asociación Internacional de Educadores Sociales. [AIEJI] (2005). Marco Conceptual de las Competencias del Educador Social. Retrieved from http://aieji.net/wp-content/uploads/2010/12/Professionalcompetences-ES.pdf

Alonso-Díaz, L. (2014). The Professional of Social Education as Trainer for Employment. Procedia Social and Behavioral Sciences, 139, 426-433.

Araújo, L., Amante, M.J., Fonseca, S., Xavier, P., Martins, E., Mendes, F., Fernandes, R., \& Magalhães, C. (2014). A prática do educador social no envelhecimento: Da formação à ação. In P. Delgado et al. (Coords.), Pedagogia/Educação Social - Teorias e Práticas: Espaços de Investigação, Formação e Ação (pp.24-28). Porto: Escola Superior de Educação do Porto. ISBN: 978-972-8969-06-6.

Bardin, L. (2015). Análise de conteúdo Lisboa: Edições 70, Lda..

Barrio, B. (2007). La evaluación de la intervención comunitaria: Un marco para la reflexión. Revista Interuniversitaria, 14, 129-138.

Capucha, L. (2008). Planeamento e avaliação de projectos - Guião prático. Lisboa: Direcção-Geral de Inovação e de Desenvolvimento Curricular.

Caride, J. (2005). Las fronteras de la pedagogia social. Perspectivas cientifica e histórica. Barcelona: Editorial Gedisa.

Caride, J. A., Pereira, O., \& Vargas, G. (2007). Educação e desenvolvemento comunitario local. Perspectivas pedagógicas e sociais da sustentabilidade. Porto: Profedições.

Crespo, L. (2010). La educación social y los servicios sociales en los procesos de desarrollo comunitario: revitalización del trabajo en red. Revista interuniversitaria de pedagogía social, 17, 137-148.

Domínguez, C., \& Blanch, J. (2013). La cualificación profesional en educación social. El papel del prácticum. Pedagogia Social. Revista Interuniversitaria, 21, 237-258.

Duta, N., Forés, A., \& Novella, A. (2015). Challenges of Social Education of Catalonia to Romania. Procedia Social and Behavioral Sciences 180, 1086 - 1093.

Moore, L., \& Avant, F. (2008). Strengthening Undergraduate Social Work Research: Models and Strategies. Social Work Research, 32(4), 231-235.

Newcomer, K, Hatry, H., \& Wholey, J. (2015). Handbook of practical program evaluation (4th ed.). New Jersey: Jossey-Bass.

Pena, R. (2005). Bateria de Slides/transparências - MPPO. Porto: Ed. Bee Consulting.

Romans, M., Petrus, A., \& Trilla, J. (2003). Profissão: Educador Social. Porto Alegre: Artmed.

Serrano (2008). Elaboração de projectos sociais: casos práticos. Porto: Porto Editora.

Silva, J. D., \& Barros, V. (2015). Avaliação de Políticas e Programas Sociais: um destaque ao sentido das variáveis contextuais. Revista Politicas Públicas, 8(2), 107-120.

Yardley, L. (2008). Demonstrating validity in qualitative psychology. In J. Smith (Ed.), Qualitative psychology. A practical guide to research methods (2nd edition) (pp. 235-251). London: SAGE. 